\title{
State Management of Social Policy in Russia
}

\author{
V.V. Moiseev \\ Belgorod State Technological University named after V.G. \\ Shukhov \\ Belgorod, 308012, Russia \\ din_prof@mail.ru
}

\author{
S.A. Chernyh \\ Orthodox gymnasium in the name of Saints \\ Methodius and Cyril of the city of Belgorod \\ svetlanachernich.2011@mail.ru
}

\begin{abstract}
The article discusses the main problems of state management of social policy in modern Russia. On the actual material, the authors show not only the main achievements but also certain shortcomings in this area during the reign of President V. Putin. The purpose of this study is to study the problems that the state must solve in order to increase the level and quality of life of Russians. Based on this goal, the authors tried to justify the new priorities of state policy in the social sphere. In this regard, this study raises the following main questions. 1. To determine the role and place of the state in the development of the social sphere. 2 . To analyze the reasons for the low level and quality of life of the population compared with the developed countries of the world. 3 . To study the effectiveness of public administration of social policy in Russia and show the ways of its further improvement. The authors hope that the implementation of the ambitious goals and objectives published in the May (2018) decree of President V. Putin will improve the lives of citizens.
\end{abstract}

Keywords—social policy, state management, problems of Russia.

\section{INTRODUCTION}

According to statistics, the real incomes of the population of Russia fall for the sixth consecutive year. The number of poor Russians is constantly increasing and even according to official figures exceeds 21 million. According to Rosstat, the number of people with incomes below the subsistence minimum increased by 0.5 million people in the 1 st quarter of 2019 to 20.9 million, which is $14.3 \%$ of the country's population [1]. Independent experts advise increasing this number by at least two times to get a true picture of the standard of living of ordinary Russians. These and other arguments and facts indicate that state management in the field of social policy is not working efficiently and is not able to solve many social problems. Moreover, the work of federal and regional authorities in this direction does not comply with the constitutional provisions on a decent life for citizens.

The Constitution of the Russian Federation proclaimed Russia a social state. Article 7 of the Basic Law, adopted by popular vote on December 12, 1993, states: "The Russian Federation is a social state whose policy is aimed at creating conditions ensuring a decent life and free development of a person”. It follows from the Constitution that the main goal of a social state is to create conditions that ensure a decent life for all citizens. In addition, the social state is obliged to direct its activities to the free development of man, providing guarantees of social protection of the population.
In Russia over the past two decades, certain attempts have been made to create conditions for improving the lives of citizens. The state has formed a general concept, main directions and priorities of social policy, created a legislative basis for their implementation. In accordance with the Basic Law, human health is protected in our country, a minimum wage is established, government support is provided for families, mothers and children, the disabled and senior citizens, a social services system is being developed, pensions, benefits and other guarantees of social protection are being established.

The main achievements of the social policy of the last decade are in the growth of real incomes of certain groups of the population compared with the Soviet period, as well as in the reduction of poverty in comparison with the crisis period of 2008-2009, when Russia had 25,000,000 Russians lived below the poverty line. This is a population of states such as Belarus, Moldova, Denmark and Switzerland combined.

The analysis shows that the number of poor Russians could be significantly reduced if the social state allocated more funds for the implementation of national priority projects, which were widely publicized by the Russian media and on which Russian citizens had high hopes. In 2008, the total financial capacity of the state, including gold and foreign exchange reserves, the Stabilization Fund and the state budget revenues, exceeded 30 trillion rubles. If desired, the state could send at least $10 \%$ of the finances at its disposal to "create conditions for a decent life" of citizens. However, according to the author's estimates, less than $1 \%$ was directed to all four national projects ("Education”, "Health”, "Affordable and comfortable housing for Russian citizens" and "Development of the agricultural sector"). And although someone called these projects "priority", judging by state funding, they can not be called that, since 3 times less money was allocated for the implementation of all four priority projects than for national security and law enforcement. And compared with defense spending, this project was planned to spend about 800 billion rubles. Even in the crisis year of 2008, 202 billion rubles were allocated for the construction of infrastructure to receive distinguished guests from APEC [2]. Wouldn't it be better to devote these enormous funds to the fight against poverty, to support the poor Russians affected by the crisis? And the APEC summit could be successfully held in the magnificent (royal) Konstantinovsky Palace, on the shores of the Gulf of Finland. Huge budget funds were spent on its restoration and rich decoration. Why stand idle for the palace and spend a lot of money from the state budget on its maintenance. 
Even in times of crisis, when the country's population especially needs state support, Putin's state allocated only 3\% of the federal budget for social needs [3].

The main goal of the state's social policy is to ensure a high level of quality of life, improving living standards for the whole society, including the social protection of citizens who, for objective reasons, need it. The nature of the social policy is determined by state power, its attitude to the concepts of "fair distribution of income", "social guarantees", "social protection", the degree of development of public organizations, civil society as a whole. Investments in the social sphere, in human capital are as important as investments in the economy and innovative development. It is no coincidence that Vladimir Putin, addressing the political elite, emphasized: "The concentration of budgetary and administrative resources on improving the quality of life of Russian citizens is a necessary and logical development of our economic course that we have been pursuing over the past five years, and we will carry on. This is a course for investing in people, and therefore - in the future of Russia. ” Despite almost three decades of endless and often stupid reforms, Russia's social policy is still characterized by low wages, modest pensions, which are barely enough to make ends meet.

In Russia, financing of social sectors (education, healthcare, demography, etc.) is still carried out on a secondary basis. A misunderstanding of the importance of effective public administration of the social sphere has already led to stagnation in the economy and a slowdown in the country's socio-economic development. In countries with a social market economy, huge investments are made annually in the social sphere. It concentrates significant material, labor and financial resources. The goals of each country are diverse, but when ranking the set of goals for the functioning and development of a country, it must be taken into account that it is social goals that unite people within the country, while economic goals can be shared with foreign entities (for example, joint ventures or enterprises with foreign capital territory of the country, transnational corporations, etc.).

\section{Problem Statement}

Carrying out this study, the authors set themselves the goal of analyzing state social policy and determining its true state, in contrast to propaganda assessments that citizens of Russia recognize through the official media and agitation.

In public speeches, President V. Putin has repeatedly argued for raising pensions and benefits for veterans, for a decent life in old age. However, his words were not always supported by effective measures, specific care for pensioners. Suffice it to say that 70 percent (!) Of Russian pensioners during the first term of his presidency received a pension below the subsistence level, that is, they lived in poverty and misery. This fact was announced by the chairman of the committee on labor and social policy of the State Duma Andrei Isaev. And only at the beginning of 2010, the income of veterans who devoted their whole life to the country was increased to a living wage. All non-working pensioners, whose total income is now below the subsistence level, began to receive social benefits in their regions. But a living wage is not a worthy life. This is the same poverty. The social state set a living wage for a pensioner in 2019 of less than 10 thousand rubles (\$ 150) [4]. And this is with high rent, often taking more than half of this minimum, with high tariffs for electricity, gas, cold and hot water, which over the past 15 years have increased by almost 10 times.

With high prices for medicines, clothes, shoes, food, under all other conditions created by the "social state", tens of millions of pensioners and labor veterans cannot live worthily in our country.

The number of pensioners in Russia, according to the Pension Fund, is approaching 40 million people. Consequently, almost $30 \%$ of Russian citizens with retirement cannot count on a decent life in old age, despite the "tireless care" of the social state about them.

Thus, the guarantor of the Constitution, which should determine domestic and foreign policy, has failed to direct the efforts of its state apparatus in accordance with the Basic Law to "create conditions ensuring a decent life" for domestic pensioners.

Everything is relative. And if we compare the average pension of Russian pensioners with the average pension in Switzerland, it turns out that our pension is ten times less than the Swiss one. In Switzerland, there is no oil, gas, other natural resources, like Russia, but the average pension reaches $\$ 4,500$ per month. Unlike Switzerland, the average pension in Russia, according to official figures, is \$ 246 [4]. It turns out that veterans in Russia are provided with the state almost 20 times worse than in Switzerland. As you can see, our social state has someone to take an example in caring for veterans. And the State Duma, where a well-known party dominates, in 2018 adopted the "draconian law" regarding labor veterans, increasing the retirement age by 5 years at once.

It cannot be said that the country's leadership, government, and the State Duma are not doing anything for a decent life for citizens. Both the president and the legislative branch, together with the executive branch, are taking measures to improve the standard and quality of life of Russians. So, in the May decrees in 2012 quite specific and important tasks were set, namely: to achieve by 2018: 1) increase the average life expectancy of Russians by 74 years (the combined age of men and women divided in half); 2) an increase in the real salary of public sector employees by 1.4-1.5 times, and in certain categories by 2 times, etc. [5]

Unfortunately, the government failed to fulfill most of the social tasks set in the presidential decrees in 6 years. For example, it was not possible to increase the average life expectancy of Russians to the planned age; it was not enough for almost 2 years to the planned indicators. Despite the fact that teachers, doctors, scientists and other state employees received some increase in salaries, it was felt only until 2014: inflation has eaten up the salaries because of the crisis, sanctions, and devaluation of the ruble. Moreover, university professors, doctors and researchers were promised a $200 \%$ increase in salaries compared to the regional average, and in fact, for example, in the Belgorod region, professors and associate professors, not to mention ordinary teachers of state universities, received an allowance for everything six years no 
more than $60 \%$. The ruble devaluation and high inflation, which was observed during this period, which led to a drop in real wages, played a negative role. And state management did practically nothing to weaken their blow to ordinary citizens of Russia. With the skyrocketing prices at the beginning of 2019, their real incomes also turned out to be very modest, not meeting the letter and spirit of the May (2012) decrees of the head of state. Putin himself stated that there were more unresolved issues in the implementation of the May 2012 decrees than fulfilled instructions [6].

In this regard, there is a need to remind readers of yet another promise of the Russian government regarding the increase in salaries for teachers and university professors, and other categories of state employees. We are talking about the so-called "Strategy 2020", approved by the government in 2008. This voluminous document formulated the main goals that the Government of the Russian Federation proposed to achieve in the country's socio-economic development until 2020, including increasing GDP by 37-38 \%, the expected life expectancy of Russians by 2.5 years, real incomes of the population by $53-54 \%$, etc. "Strategy 2020" includes five-fold increase in salaries, four-fold increase in pensions, three-fold p Ost housing construction.

Among the main indicators of social policy, which the Russian government was planning to achieve after 10 years of active work, was the size of wages. The average wage, recorded in Strategy 2020, will increase from 526 to \$2700 [7]. However, the official labor contract signed by one of the authors of this article on December 27, 2018 says that his official salary is 38,700 rubles or less than 600 US dollars. As you can see, from the planned by the government to the reality - "a huge distance."

Here, the authors would like to draw attention to the amazing feature of modern state management, headed by President V. Putin. Officials practice reporting on the work is done... plans for the future. At the same time, they forget their promises made publicly to Russian citizens. This happened with promises to improve the standard of living of ordinary Russians, which was planned to be achieved by 2020. The president and government of the United Russia party are safely forgotten. Instead, they are actively discussing new plans and goals that they want to achieve by 2024. Such a national peculiarity has appeared in recent years: the president reports on the fulfillment of the promises made earlier to the people ... with plans for the future. The people believe President Putin that under his leadership a decree of May 7, 2018, on improving the lives of Russians by 2024 [8] will be implemented.

In order to implement plans in the social sphere, the president and his state management necessary:

1) to overcome the flagrant social injustice created by privatization;

2) move to a new system of values so that there are no poor in a rich country;

3) significantly increase the level of wages, pensions, benefits and other payments, guided by European standards, in order to bridge the huge gap between the rich and the poor;
4) increase the social protection of the population;

5) not in words but in practice to implement the "Strategy 2020”.

Only in this case, the president, together with his federal and regional authorities, will be able to fulfill his promises that in 2020 Russia will become "a country respected in the world and at the same time comfortable for living”.

And to Russian citizens would like to say: it's time, finally, to evaluate politics not by his beautiful words and numerous promises, but by his specific needs.

The authors do not want to be misunderstood. They were not going to paint the entire social policy of Russia with black paint. They only wanted to show the problems and shortcomings of state management in this area.

It should be noted here that over the past decade, there have been positive trends in solving problems in the social sphere. So, to stimulate the birth rate and solve the demographic problem, the so-called "maternal capital" was introduced. Maternal capital is a huge help to all Russian families where two or more children were born. The program was adopted ten years ago, and overall these years more than eight million families of our country have received payments. We started with 250 thousand rubles and indexed the amount almost every year. In 2019, its size is 453,026 rubles (about $\$ 7,000)[9]$.

Not all parents can get maternity capital, but only those who have given birth or adopted a second child. And not immediately after adding to the family, but 3 years after this joyful event. Maternal capital, unfortunately, has limitations: it cannot be spent on any goals, but only on those indicated by the government - on education, home improvement and retirement for mom [10]. In addition, at the birth of children, mothers receive various benefits from the state. For example, maternity allowance (for maternity) and monthly payments for childcare up to 1.5 years. From February 1, 2019, children's benefits were increased by $4.3 \%$ [11]. For some reason, the state decided to save on children's allowances after they reached one and a half years: until recently, it was only 50 rubles (less than one dollar) per month! And only on August 2, 2019, the president signed the law on increasing monthly payments for a child aged 1.5 to 3 years, equivalent to the size of the child's living wage (approximately \$ 150) [12].

The size of the article does not allow analyzing the entire social policy pursued by the state in our country. But even with these examples, quite well, in our opinion, one can trace its main trends. And if we summarize the arguments and facts presented, we can make a completely reasonable conclusion: state management does not fully implement the constitutional provisions on a decent life. Neither child benefits, nor pensions for labor veterans, nor salaries for teachers and professors guarantee a decent life in Russia. All of them are still very far from European social standards.

The size of the article does not allow us to analyze all the social policies pursued by the state in our country. But even with these examples, in our opinion, it is quite possible to trace its main trends. And if we summarize the arguments and facts 
presented, we can make a completely reasonable conclusion: public administration does not fully implement the constitutional provisions on a decent life. Neither child allowances, nor pensions for labor veterans, nor salaries for teachers and professors guarantee a decent life in Russia. All of them are still very far from European social standards. Moreover, neither the education system, including pre-school, school and higher), nor health care, nor social protection and other areas of social policy meet modern requirements. It is no accident, therefore, that Russia occupies prestigious places in world ratings in terms of level, quality and life expectancy of citizens.

One of the most successful, in our opinion, ratings is the Legatum Prosperity Index agency. When calculating the data, it focuses not only on national indicators but also on the quality of life of the population itself, taking into account salary levels, the educational system, the ratio of prices in the state and the real financial situation of the average citizen.

According to this agency, Russia in the world list in 20182019 takes 61 out of 142 places, located between such backward countries as Sri Lanka and Vietnam. In some other world ratings relating to certain areas of social policy, Russia is in the second hundred countries, for example, in 115th place, losing to Sierra Leone, the state in West Africa [13].

\section{RESEARCH QUESTIONS}

In this study, the author considers the following questions.

1. The role and place of the state in the development of the social sphere.

2 .The reasons for the low level and quality of life of the population compared with the developed countries of the world.

3. Effectiveness of public administration of social policy in Russia.

\section{PURPOSE OF THE STUdY}

The main purpose of the research is to analyze the current problems of the state management of the Russian economy in order to offer recommendations for accelerating economic development.

\section{RESEARCH METHODS}

When studying the main issues of the topic, the author uses the following methods:

1) an institutional method to analyze the activities of the President, the government and other authorities in the implementation of social policy;

2) the method of comparative analysis was used by the authors to compare Russian social policy with the social policy of other countries;

3) a systematic method that allows you to create a holistic view of the state of Russian social policy and the effectiveness of state management in this area of activity.

\section{CONCLUSION}

As conclusions, the following should be noted.
1. The historical experience of Russia convincingly shows that if reforms in the economy and social sphere are not timely implemented, delayed or halfway implemented, without solving the basic socio-economic problems, this may cause the country to lag behind the developed countries of the world, and cause an economic crisis. In addition, a number of sociologists and political scientists have warned that failure to conduct timely reforms could result in a social explosion, a "color" revolution like the Orange Revolution in Ukraine, the "Rose Revolution" in Georgia, or the "Tulip Revolution" in Kyrgyzstan. In these post-Soviet states, the authorities could not cope with the mass indignation of huge sections of society who were dissatisfied with the conditions of their life in the 21st century.

2. Russia has someone to take an example in the implementation of socio-economic transformations. In Norway, for example, the influx of petrodollars in a relatively short period of time eliminated the mass poverty of their citizens. In 2007, the average pension in Norway exceeded 3,000 US dollars, unemployment benefits began to account for half of the lost income. As a result of the measures taken, this Scandinavian state has become one of the three world leaders in terms of living standards.

Similar transformations took place in the social sphere of Middle East Qatar, when oil reserves were explored and its export began. There, they not only pay $\$ 10,000$ at the birth of their first child but also give out immediately $\$ 270,000$ to create the life of a young family [14]. Education and healthcare, light and water in this country are free, as under socialism. Such social assistance to young people entering their lives is also found in other hydrocarbon exporting states. But what is noteworthy, the number of dollar billionaires in Qatar and Norway is significantly inferior to Russia. Maybe that's why social stratification and poverty are not so evident.

3. The image of any country depends, as you know, on how well the population lives in it and on how well the state authorities cope with their duties. Perhaps for these reasons, the international image of Russia leaves much to be desired. Today, one should not be proud of the growing military spending (Russia ranks third in the world here) [15], but of how comfortable the people live. And in this matter, the state management of the Russian Federation, unfortunately, has nothing to be proud of.

4. Given the current scarcity of financial resources, it is necessary to move from the principle of social assistance to all citizens to targeted assistance to those who really need it. Control over the use of extra-budgetary trust funds should be strengthened, and liability for violation of the law should be strengthened. Concrete actions have to be taken to solve serious social problems, the most important of which are: a high level of poverty and significant differentiation of the monetary incomes of the population; unfavorable demographic situation; widespread benefits and compensation payments without taking into account the need of recipients; underfunding of socio-cultural organizations. To solve social problems, it is necessary to ensure universal accessibility and socially acceptable quality of the most important social 
benefits, which include, first of all, medical, social services and general education.

5. The main task of social policy in capitalist Russia today, in our opinion, is the need to ensure the most effective protection of socially vulnerable categories of citizens who do not have the ability to independently solve social problems and need state support; it is necessary to reduce social and economic poverty, as well as strengthen insurance principles for social protection of the population upon retirement, in case of illness, in case of industrial accidents and occupational diseases.

For the able-bodied population, economic conditions must be created that allow citizens to ensure a higher level of social consumption at the expense of their own incomes, including comfortable housing, the better quality of education and health services, and a decent standard of living in old age. It is also necessary to create conditions for effective employment of the population, ensuring a balance of supply and demand in labor markets, including through improving the quality and competitiveness of the workforce, as well as the development of migration processes. Continue the reform of labor legislation aimed at balancing the interests of workers, employers and the state, and bringing it into line with the requirements of a market economy. According to studies by Russian economists and sociologists, at the end of 2018, about a quarter of Russians were not satisfied with their financial situation, and more than a third of the population noted a further deterioration of life [16]. This is how ordinary people speak of their lives in the country in which they live. "Every morning, when I listen to the anthem of our vast impoverished country, my soul is torn from the words" we are proud of you. " What are we proud of? The oligarchs? Bribe takers? Selling policies? In the country - the complete collapse of industry, agriculture, education, medicine. Closed schools, kindergartens. And on TV they tell us that life is beautiful" [17, p. 413]. These words of ordinary Russians contain an assessment of the work of state management, which today conducts social policy in Russia.

The authors, not sharing the opinion of many Russians dissatisfied with social and economic policies, express hope for the best. They still believe that President Vladimir Putin's decree 2018 on the breakthrough development of Russia in the economy and social sphere will be translated into concrete actions to improve the lives of tens of millions of Russians.

\section{REFERENCES}

[1] There are more poor people in Russia. - URL: https://www.vedomosti.ru/economics/articles/2019/07/29/807554-vrossii-bolshe-bednih.

[2] Moiseev V.V. Actual Problems of social Policy in Russia/ Education, Science, Technology, Innovation and Life, 2019, pp. 425-432.

[3] Kashin V. Budget three-year plan - a sweet pill with a bitter filling // Russian Federation Today, 2008, Vol. 20, p. 32.

[4] The average pension in Russia in 2019: all relevant information Source. - URL: https://creditnalichnimy.ru/ srednyaya-pensiya-v-rossii.

[5] Decree of the President of the Russian Federation of 05.07.2012 No. 597 "On measures for the implementation of state social policy". - URL: http://kremlin.ru/acts/bank/35261

[6] Five years of Putin's May decrees: that was never done. - URL: https://www.bbc.com/russian/features-39800893.

[7] Speech at the enlarged meeting of the State Council "On the development strategy of Russia until 2020” - URL: http://kremlin.ru/events/president/transcripts/24825.

[8] The President signed the Decree "On the national goals and strategic objectives of the development of the Russian Federation for the period up to 2024”. - Retrieved from: http://kremlin.ru/events/president/news/ 57425.

[9] Maternity capital in 2019. - URL: https://materinskij-kapital.ru/v-2019godu/

[10] Federal Law of December 29, 2006 N 256-Ф3 "On Additional Measures of State Support for Families with Children". - URL: http://www.consultant.ru/document/ cons_doc_LAW_64872/2189b09639d1af2baefd5a961675b0b99b8a765 2/

[11] Benefits on children in 2019. - URL: http://posobie-expert.ru/posobiyav-2019-godu/

[12] Putin signed a law to increase benefits for children under three. - URL: https://news.mail.ru/society/38205000/? frommail=1

[13] New ratings of countries of the world, compiled by the standard of living. - $\quad$ URL: http://finansiko.ru/uroven zhizni_naseleniya_rossii_stran_mira_2014/

[14] Moiseev V.V., Zhigaeva K.V., Kramskoy S.I. Social policy in Russia: promises and reality/Advances in Social Science, Education and Humanities Research (ASSEHR), 2019, Vol. 322, pp. 633-638.

[15] "Real" spending of Russia on defense was called in the United States. URL: https://www.amic.ru/news/439530/

[16] Makeev N. The financial situation of Russians has worsened: no bright future is expected. - URL: https://www.mk.ru/ economics/2019/01/23/materialnoe-polozhenie-rossiyan-ukhudshilossvetlogo-budushhego-ne-predviditsya.html.

[17] Moiseev V.V. Social policy of modern Russia. Monograph. Berlin: Direct Media Publishing House, 2019, p. 448. 